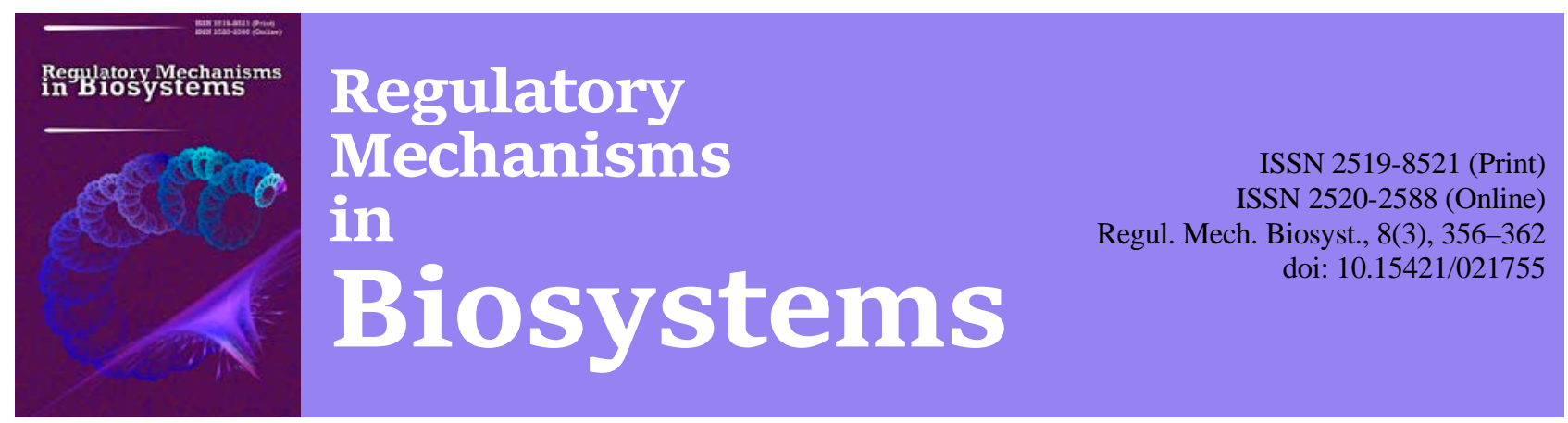

\title{
Bile lipids in rats under chronic social stress
}

\author{
A. M. Liashevych, I. I. Tubaltseva, Y. M. Reshetnik, O. V. Bondarenko, S. P. Veselsky, M. Y. Makarchuk \\ Taras Shevchenko National University of Kyiv, Kyiv, Ukraine
}

Article info

Received 02.07.2017

Received in revised form 11.08.2017

Accepted 13.08.2017

Taras Shevchenko

National University of Kyiv,

Glushkova Str., 2, Kyiv,

03022, Ukraine.

Tel.: +38-063-050-22-30.

E-mail:

lam88leona2@gmail.com
Liashevych, A. M., Tubaltseva, I. I., Reshetnik, Y. M., Bondarenko, O. V., Veselsky, S. P., \& Makarchuk, M. Y. (2017). Bile lipids in rats under chronic social stress. Regulatory Mechanisms in Biosystems, 8(3), 356-362. doi: 10.15421/021755

Our experiments studied changes in lipid compound of bile of non-purebred male rats under the condition of social stress while the preparation "Korvitin” was used against the stress. Using the method of thin-layer chromatography, we determined the concentrations of phospholipids, cholesterol and its esters, free fatty acids and triglycerides in the animals' bile, which was obtained through vivesection a day and a month after the rats were first subjected to chronic social stress (model of social defeat), and also in the bile of the animals which were treated intragastrically with "Korvitin" against the stress (1 mg/kg, 7 days). In the bile of the male rats which experienced chronic social stress the concentration of free cholesterol decreased and the content of its esters increased both immediately after the initiation of stress and after a month of exposure to stress. The concentration of free fatty acids in the bile decreased after modeling chronic social stress, but increased in liver secretion, taken a month after the animals had first experienced stress. In the bile of male rats immediately after the procedure of exposing the animals to stress, the content of phospholipids decreased. Using "Korvitin" during the modeling of social stress caused decrease in the content of phospholipids in the rats' bile and caused significant increase in the concentration of free fatty acids, triglycerides and cholesterol esters in the liver secretion. The study found significant changes in the concentration of lipids in the bile and in their distribution in the organism of male rats under the conditions of experimentally induced chronic stress. The effect of stress on the bile of rats requires further study for determining its pathogenic role.

Keywords: liver; bile cholesterol; bile phospholipids; bile fat acids; bile triglycerides; Korvitin; social defeat

\section{Ліпіди жовчі самців щурів в умовах хронічного соціального стресу}

\author{
А. М. Ляшевич, І. І. Тубальцева, Є. М. Решетник, С. П. Весельський, О. В. Бондаренко, М. Ю. Макарчук
}

\section{Київський національний університет імені Тараса Шевченка, Київ, Україна}

В експериментах на безпородних самцях щурів досліджено зміни ліпідного складу жовчі за хронічного соціального стресу та застосування корвітину за цих умов. Методом тонкошарової хроматографії визначено концентрації фосфоліпідів, холестролу та його етерів, вільних жирних кислот і тригліцеридів у жовчі, зібраній у гострих дослідах через добу та через місяць після того, як щурі зазнали хронічного соціального стресу (у моделі соціальної поразки), а також у тварин, які у процесі стресування отримували інтрагастрально корвітин (1 мг/кг, 7 діб). У жовчі самців щурів, які зазнали експериментального хронічного соціального стресу, знижувалася концентрація вільного холестеролу та збільшувався вміст його етерів як одразу після завершення стресування, так і через місяць після нього. Концентрація вільних жирних кислот у жовчі знижувалася після завершення моделювання хронічного соціального стресу, але зростала у печінковому секреті, зібраному через місяць по тому як тварини зазнали стресового впливу. У жовчі самців щурів одразу після завершення процедури стресування знижувався вміст фосфоліпідів. Застосування корвітину під час моделювання соціального стресу у щурів запобігало зниженню вмісту фосфоліпідів у жовчі та викликало істотне збільшення концентрації вільних жирних кислот, тригліцеридів і етерів холестеролу у печінковому секреті. Виявлені суттєві зміни концентрації ліпідів у жовчі, а отже, і їх розподілу в організмі самців щурів в умовах експериментального хронічного стресу потребують подальшого вивчення для з'ясування їх патогенетичної ролі.

Ключові слова: печінка; холестерол жовчі; фосфоліпіди жовчі; жирні кислоти жовчі; тригліцериди жовчі; корвітин; модель соціальної поразки

\section{Вступ}

Жовч як унікальна біологічна рідина містить різні складові та виконує численні важливі функції в організмі (Boyer, 2013). Жовчоутворення відіграє ключову роль у метаболізмі холестеролу, виступаючи основним шляхом його екскреції як у вигляді синтезованих із нього в гепатоцитах жовчних кислот, так і його вільної та етерифікованої форм. I хоча холестероловий гомеостаз не обмежується синтезом холестеролу в гепа- тоцитах та його виведенням у складі жовчі, порушення його надходження до жовчі спричинює серйозні розлади жовчосекреторної функції та патологічні стани гепато-біліарної системи (Hşmioğullari et al., 2007; Wang et al., 2009; Tyazhka et al., 2015). До основних ліпідних складових жовчі крім холестеролу та жовчних кислот належать фосфоліпіди (переважно діацилфосфатидилхолін). Завдяки детергентним властивостям жовчні кислоти забезпечують надходження ліпідів (перш за все фосфатидилхоліну) з каналікулярного домену плазматичної мем- 
брани гепатоцитів до жовчі (Boyer, 2013; Eckstein et al., 2015; Linton, 2015). У свою чергу, фосфоліпіди жовчі виконують захисну функцію, зменшуючи детергентні ефекти холатів (Nicolaou et al., 2015). За фізіологічного стану в жовчі людини та інших ссавців жовчні кислоти та фосфоліпіди утворюють із холестеролом комплекси - міцели. У випадку порушення співвідношення концентрацій цих компонентів у жовчі створюються умови для випадання холестеролу в осад та його кристалізації (Hşmioğullari et al., 2007; Wang et al., 2009), проявляються токсичні ефекти жовчних кислот тощо (Linton, 2015; Nicolaou et al., 2015).

Надходження ліпідів до жовчі та підтримання певного їх співвідношення у печінковому секреті - важливий фізіологічний процес, що значною мірою відображає перебіг ліпідного обміну у клітинах печінки та в організмі в цілому (Tyazhka et al., 2015). Зміни обміну ліпідів і пов’язані з ними патології характерні для різних форм стресу, вони виявляються у тварин різних видів і людини (Zahayko et al., 2008; Chuang et al., 2010; Han et al., 2016). Відомі прямі ефекти гострого теплового стресу на ліполіз та ліпогенез в адипоцитах (Faylon et al., 2015). Соціальний стрес спричиняє ожиріння та супутні захворювання (Scott et al., 2012). Хронічний стрес викликає жирове переродження печінки з одночасною втратою вісцерального жиру (Liu et al., 2014). Відмічаються як швидкі (оксидативний стрес, запалення), так і тривалі (метаболічні розлади, активація окремих ланок метаболічних перетворень ксенобіотиків та ліпідів, внутрішньопечінкове накопичення тригліцеридів, лімфоцитарна інфільтрація, асцит тощо) порушення структури та функціонування печінки, викликані посттравматичним стресовим розладом, що зумовлює виникнення дисліпідемії та метаболічного синдрому (Gautam et al., 2015).

Серед сучасних медико-біологічних досліджень ліпідного обміну, гіпо- та гіперхолестеринемії та пов'язаних із ними метаболічного синдрому, атеросклерозу, ішемічної хвороби серця чільне місце посідає вивчення відповідних лікувальних засобів (Dlyaboha, 2012; Liashevych et al., 2017). Зокрема, біофлавоноїди змінюють ліпідний склад крові та жовчі, впливають на жовчосекреторну функцію печінки лабораторних тварин (Liashevych et al., 2016; Vovkun et al., 2016). Критична роль стресіндукованих порушень метаболізму ліпідів у розвитку багатьох патологічних станів, невиправдано мала кількість сучасних досліджень жовчосекреторної функції печінки в умовах соціального стресу та актуальність пошуку ефективних препаратів для корекції патологічно зміненого ліпідного обміну зумовили мету цієї статті - виявити вплив хронічного соціального стресу на ліпідний склад жовчі самців щурів одразу по завершенні процедури стресування, у віддаленому періоді часу (через місяць) та під час застосування корвітину у стресованих тварин.

\section{Матеріал і методи досліджень}

Дослідження провели на 48 білих безпородних щурах у віварії ННЦ «Інститут біології та медицини» Київського національного університету імені Тараса Шевченка. Всі експерименти проводили відповідно до існуючих міжнародних і національних вимог і норм гуманного поводження 3 експериментальними тваринами. Тварин утримували у пластикових клітках із гратчастим залізним верхом індивідуально (експериментальні тварини) або гаремом (один самець разом із 2-4 самицями). Режим освітлення у віварії - природний. Упродовж усього експерименту підтримували належний температурний режим. Тварини отримували стандартний раціон (комбікорм для лабораторних щурів Вітамекс, Україна), мали вільний доступ до води та їжі. Після одержання тварин їх індивідуально помічали шляхом нанесення перманентним маркером номера на хвіст. Від першого до останнього дня дослідження контролювали масу тіла експериментальних тварин.

Двадцять один щур масою $0,20 \pm 0,03$ кг використаний як інтрудер для створення хронічного соціального стресу - мо- дель соціальної поразки. Інші 21 щур масою 0,35-0,40 кг, кожного яких утримували разом із 2-4 самицями, слугували як доместики в цій моделі стресу. Щури-інтрудери $(\mathrm{n}=21)$ зазнавали впливу хронічного соціального стресу в моделі соціальної поразки упродовж 14 діб. П'ятеро з них із сьомої по чотирнадцяту добу процедури стресування отримували інтрагастрально корвітин у дозі 1 мг/кт маси тіла тварини. Тварини контрольної групи масою $0,20 \pm 0,03$ кг (n=6) також отримували стандартний раціон і мали вільний доступ до води, але не зазнавали впливу хронічного соціального стресу в моделі соціальної поразки.

Використана у нашому дослідженні модель соціального стресу (модель соціальної поразки) забезпечила набуття інтрудерами субординантного статусу та мала достатню тривалість для формування у них відповідного поведінкового стереотипу. Модифікована модель хронічного соціального стресу розроблена для мишей, у ній стрес спричиняв повторний досвід соціальних поразок у щоденних міжсамцевих конфронтаціях (Kudryavtseva, 1991; Horid'ko et al., 2017). Процедура соціального стресу починалася 3 тижневої ізоляції щурів-інтрудерів для усунення їх попереднього соціального досвіду. Надалі щурівінтрудерів протягом усього часу досліду утримували індивідуально (в окремих клітках). За три доби до початку стресу тестували щурів-доместиків на наявність агоністичної поведінки шляхом підсаджування до них у клітки індиферентних щурів, які не входили до складу експериментальної групи. Доместиків, які не демонстрували агресивної поведінки, виключали 3 експерименту.

Стрес створювали щоденними агоністичними взаємодіями між тваринами. За 10 хв до початку агоністичних взаємодій із кліток щурів-доместиків відсаджували самок. Кожного дня упродовж 14 діб у затемненій кімнаті, у другій половині доби у клітку до доместика підсаджували інтрудера на 10 хв для агоністичних взаємодій. Після цього на 20 хв у клітці встановлювали прозору перфоровану перегородку, що давала можливість візуального, нюхового та слухового, але не фізичного контакту між щуром-інтрудером і щуром-доместиком. Активність доместиків та кількість їх атак підраховували. Одночасно відслідковували поведінку інтрудерів під час перебування в одній клітці з доместиком.

Для дослідження тривалості можливих ефектів хронічного соціального стресу на ліпідний склад жовчі тварин ділили на дві групи: у першій $(\mathrm{n}=10)$ забирання жовчі проводили через добу після завершення процедури стресування (група I), а у другій $(\mathrm{n}=6)$ - через місяць після неї (група II). Самці щурів групи II упродовж місяця після моделювання в них хронічного соціального стресу перебували у приміщенні віварію в одній окремій клітці, отримували стандартний раціон і мали вільний доступ до води та їжі. Тварини, які інтрагастрально отримували упродовж другого тижня стресування корвітин у дозі 1 мг/кг маси тіла, складали експериментальну групу III $(\mathrm{n}=5)$. Зразки жовчі відбирали в групі III у той же час, що й у групі I.

Жовчосекреторну функцію щурів-інтрудерів досліджували in vivo в гострих експериментах, використовуючи для наркотизації тіопентал натрію в дозі 60 мг/кг маси тіла тварини. Перед оперативним втручанням, необхідним для отримання печінкового секрету, тварин піддавали харчовій депривації упродовж однієї доби, але при цьому вони мали вільний доступ до води. Після лапаротомії канюлювали жовчну протоку, і через 30 хв стабілізації стану тварини здійснювали протягом наступних 3 годин гострого досліду забирання 18 10-хвилинних проб жовчі. Кожні три 10-хвилинні порції жовчі збирали до одного епендорфа, надалі методом тонкошарової хроматографії, модифікованим у нашій лабораторії, визначали вміст жовчних кислот, фосфоліпідів, холестеролу та його етерів, вільних жирних кислот і тригліцеридів у всіх півгодинних зразках печінкового секрету (Vesel's'kyy et al., 2001).

За концентраціями окремих фракцій ліпідів (холестерол, етери холестеролу) та сумарних жовчних кислот розраховували холато-холестероловий коефіцієнт (коефіцієнт літогенності 
жовчі), коефіцієнт етерифікації холестеролу (співвідношення вільного холестеролу до його етерів) та співвідношення фосфоліпідів до загального холестеролу жовчі (Hanytkevych et al., 1985). Статистичну обробку даних проводили з використанням пакета Statistica 7.0 (StatSoft Inc., USA) з урахуванням t-критерію Стьюдента за нормального розподілу даних і непараметричного критерію Мана - Уїтні - за ненормального розподілу. Нормальність розподілу оцінювали за допомогою тесту Шапіро - Уїлка. Статистично значущими вважали відмінності за $\mathrm{P}<$ 0,05 (Filimonova et al., 2004, 2005).

\section{Результати}

Функції жовчі як травного секрету виконуються нею лише за умови необхідної концентрації в ній відповідних органічних компонетів, перш за все, жовчних кислот і ліпідів, та за підтриманння належного співвідношення цих речовин у печінковому секреті. За хронічного соціального стресу у печінці самців щурів відбуваються метаболічні процеси, які викликають зміни ліпідного складу жовчі. Проведене одразу по завершенні процедури хронічного соціального стресу (моделі соціальної поразки) дослідження жовчі самців щурів групи I виявило зниження концентрацій вільного холестеролу, вільних жирних кислот i, в останній пробі печінкового секрету, - фосфоліпідів жовчі (табл. 1, 2). Концентрація фосфоліпідів у шостій пробі жовчі щурів групи I зменшувалася на $11,7 \%$ ( $\mathrm{P}<0,01)$ порівняно $з$ контролем (табл. 1).

Через місяць після стресування у щурів не спостерігали суттєвих змін вмісту фосфоліпідів у жовчі порівняно з контролем. Під час застосування корвітину упродовж останнього 3 двох тижнів процедури стресування вміст фосфоліпідів у жовчі самців щурів групи III статистично значимо не відрізнявся від контролю (табл. 1).

\section{Таблиця 1}

Концентрація ліпідів у жовчі щурів самців під час хронічного соціального стресу та застосування корвітину (1 мг/кг) $(\mathrm{M} \pm \mathrm{SD}, \mathrm{M \Gamma} \%, \mathrm{n}=21)$

\begin{tabular}{|c|c|c|c|c|}
\hline \multirow{2}{*}{$\begin{array}{l}\text { Проби } \\
\text { жовчі }\end{array}$} & \multirow{2}{*}{ Серія } & \multicolumn{3}{|c|}{ Фракції ліпідів жовчі } \\
\hline & & фосфоліпіди & вільні жирні кислоти & тригліщериди \\
\hline \multirow{4}{*}{1} & контроль & $69,74 \pm 6,66$ & $12,14 \pm 2,15$ & $2,33 \pm 0,93$ \\
\hline & група I & $71,21 \pm 7,51$ & $10,01 \pm 2,24$ & $2,05 \pm 0,26$ \\
\hline & група II & $69,68 \pm 7,70$ & $21,03 \pm 2,52 * * *$ & $2,90 \pm 0,55$ \\
\hline & група III & 67,96 & $19,82^{* * *}$ & 2,26 \\
\hline \multirow{4}{*}{2} & контроль & $68,73 \pm 6,05$ & $12,59 \pm 2,51$ & $2,30 \pm 0,61$ \\
\hline & група I & $72,01 \pm 7,63$ & $9,81 \pm 1,77^{*}$ & $2,04 \pm 0,31$ \\
\hline & група II & $70,85 \pm 6,82$ & $20,65 \pm 2,99 * * *$ & $2,65 \pm 0,46$ \\
\hline & група III & 70,24 & $19,28 * *$ & 2,60 \\
\hline \multirow{4}{*}{3} & контроль & $67,19 \pm 4,15$ & $12,57 \pm 2,02$ & $2,29 \pm 0,83$ \\
\hline & група I & $68,97 \pm 7,02$ & $11,20 \pm 2,03$ & $2,15 \pm 0,29$ \\
\hline & група II & $68,17 \pm 5,11$ & $20,68 \pm 2,35 * * *$ & $2,72 \pm 0,40$ \\
\hline & група III & 70,80 & $18,78^{* *}$ & 2,52 \\
\hline \multirow{4}{*}{4} & контроль & $66,31 \pm 3,76$ & $12,37 \pm 1,64$ & $2,19 \pm 0,68$ \\
\hline & група I & $66,38 \pm 6,33$ & $10,46 \pm 1,67^{*}$ & $2,03 \pm 0,30$ \\
\hline & група II & $65,72 \pm 5,16$ & $19,72 \pm 2,21^{* * *}$ & $2,52 \pm 0,51$ \\
\hline & група III & 70,98 & $18,62 * *$ & 2,66 \\
\hline \multirow{4}{*}{5} & контроль & $64,10 \pm 4,44$ & $12,74 \pm 1,52$ & $1,96 \pm 0,69$ \\
\hline & група I & $60,42 \pm 6,49$ & $9,39 \pm 2,22^{* *}$ & $1,85 \pm 0,24$ \\
\hline & група II & $62,97 \pm 5,61$ & $18,48 \pm 1,92 * * *$ & $2,42 \pm 0,35$ \\
\hline & група III & 66,78 & $20,98 * *$ & $2,78^{*}$ \\
\hline \multirow{4}{*}{6} & контроль & $62,67 \pm 4,01$ & $12,97 \pm 1,59$ & $1,96 \pm 0,63$ \\
\hline & група I & $55,35 \pm 4,83 * *$ & $8,24 \pm 1,13^{* * *}$ & $1,73 \pm 0,24$ \\
\hline & група II & $60,53 \pm 4,49$ & $17,88 \pm 1,71^{* * *}$ & $2,38 \pm 0,41$ \\
\hline & група III & 63,38 & $21,50 * * *$ & 2,96* \\
\hline
\end{tabular}

Примітки: * - $\mathrm{P}<0,05, * *-\mathrm{P}<0,01, * * *-\mathrm{P}<0,001$ статистично значимі відмінності порівняно з контролем.

Максимальне зниження концентрації вільних жирних кислот на $36,5 \%(\mathrm{P}<0,001)$ виявлене у шостій пробі жовчі щурів групи I (табл. 1). I навпаки, через місяць після завершення процедури хронічного соціального стресу у самців щурів концен- трація вільних жирних кислот у жовчі зросла. Так, у шостій пробі вміст вільних жирних кислот збільшився на 37,9\% (P < $0,001)$ порівняно з контролем. При цьому як у жовчі, зібраній у тварин одразу після моделювання хронічного соціального стресу, так і у зразках, взятих через місяць після нього, концентрація тригліцеридів не змінювалася порівняно 3 контролем. Натомість у тварин, які зазнали соціальної поразки та отримували корвітин, концентрація вільних жирних кислот і тригліцеридів зросла порівняно з контролем (табл. 1). Наприкінці гострого досліду (шоста проба) у групі III вміст вільних жирних кислот у жовчі вищий від контролю на 65,8\% (P < 0,001), а тригліцеридів - на 51,0\% (P < 0,001).

Таблиця 2

Концентрація холестеролу та його етерів у жовчі щурів самців під час хронічного соціального стресу та застосування корвітину $(1$ мг/кг) $(\mathrm{M} \pm \mathrm{SD}$, мг $\%, \mathrm{n}=21)$

\begin{tabular}{|c|c|c|c|}
\hline \multirow{2}{*}{$\begin{array}{l}\text { Проби } \\
\text { жовчі }\end{array}$} & \multirow{2}{*}{ Серія } & \multicolumn{2}{|c|}{ Вільний та етерифікований холестерол жовчі } \\
\hline & & холестерол & етери холестеролу \\
\hline \multirow{4}{*}{1} & контроль & $28,60 \pm 3,87$ & $2,64 \pm 0,49$ \\
\hline & група I & $21,24 \pm 3,15^{* *}$ & $3,18 \pm 0,68$ \\
\hline & група II & $23,27 \pm 3,63^{*}$ & $2,73 \pm 0,67$ \\
\hline & група III & $20,90 * *$ & $3,34 *$ \\
\hline \multirow{4}{*}{2} & контроль & $28,83 \pm 3,82$ & $2,51 \pm 0,45$ \\
\hline & група I & $20,97 \pm 1,65^{* *}$ & $2,88 \pm 0,58$ \\
\hline & група II & $24,13 \pm 2,59 *$ & $2,95 \pm 0,62$ \\
\hline & група III & $21,94 * *$ & $3,60 * *$ \\
\hline \multirow{4}{*}{3} & контроль & $27,11 \pm 3,21$ & $2,53 \pm 0,46$ \\
\hline & група I & $21,23 \pm 3,44^{* *}$ & $2,95 \pm 0,48$ \\
\hline & група II & $23,35 \pm 1,40^{*}$ & $3,03 \pm 0,50$ \\
\hline & група III & $22,10 * *$ & $3,88^{* *}$ \\
\hline \multirow{4}{*}{4} & контроль & $26,06 \pm 4,86$ & $2,39 \pm 0,48$ \\
\hline & група I & $19,10 \pm 2,10^{* *}$ & $3,00 \pm 0,43^{*}$ \\
\hline & група II & $22,10 \pm 1,09$ & $2,83 \pm 0,51$ \\
\hline & група III & 22,58 & $3,78^{* * *}$ \\
\hline \multirow{4}{*}{5} & контроль & $24,54 \pm 4,84$ & $2,39 \pm 0,55$ \\
\hline & група I & $16,96 \pm 1,27 * *$ & $2,79 \pm 0,47$ \\
\hline & група II & $20,53 \pm 1,67$ & $2,65 \pm 0,47$ \\
\hline & група III & 20,96 & $3,54^{* *}$ \\
\hline \multirow{4}{*}{6} & контроль & $24,16 \pm 4,76$ & $2,50 \pm 0,60$ \\
\hline & група I & $16,79 \pm 1,94^{* *}$ & $2,60 \pm 0,48$ \\
\hline & група II & $20,45 \pm 1,07$ & $2,62 \pm 0,57$ \\
\hline & група III & 19,58 & $3,64^{* *}$ \\
\hline
\end{tabular}

Примітки: див. табл. 1.

За хронічного соціального стресу у гепатоцитах самців щурів переважно пригнічуються процеси, які забезпечують надходження у первинні жовчні канальці стероїдних ліпідних компонентів жовчі. Спостерігали більше зниження концентрації холестеролу в усіх зразках жовчі тварин групи I (одразу після моделювання соціального стресу). Концентрація холестеролу у першій пробі жовчі групи I менша на 25,7\% (P < 0,01) від контролю, а в останній, шостій пробі - на 41,3\% (Р < 0,01; табл. 2).

У самців щурів групи II вміст вільного холестеролу в жовчі у першій - третій пробах менший за контроль на 18,7\% (P < 0,05), 16,3\% (P < 0,05), 13,9\% (P < 0,05), відповідно, але далі (у четвертій, п’ятій та шостій пробах) його концентрація статистично значимо не відрізняється від показників контрольної групи (табл. 2). Під час уведення стресованим тваринам корвітину подібним чином пригнічується надходження вільного холестеролу у жовчні канальці. У групі III концентрація холестеролу у першому зразку жовчі менша за контроль на 26,9\% (P < $0,01)$, у другому - на 23,9\% ( $<<0,01)$, а у третьому - на $18,5 \%$ $(\mathrm{P}<0,01)$. Слід відмітити підвищену порівняно 3 контролем концентрацію етерів холестеролу у жовчі щурів групи III (табл. 2). У першій півгодинній пробі жовчі групи III вміст етерів холестеролу зростав порівняно 3 контролем на 26,5\% (P $<0,05)$, а в останній, шостій, - на 45,6\% (P < 0,01).

Таким чином, жовч стресованих щурів групи I мала такі відмінності за вмістом ліпідів порівняно з контролем: у першій пробі в цій групі частка вільних жирних кислот складає лише 
$9 \%$, а холестеролу - 20\%, тоді як фосфоліпідів - 66\%, а етерів холестеролу $-3 \%$ (рис. 1 ).

Через місяць після проведення процедури стресування (група II) у жовчі виявляється протилежний порівняно 3 групою I феномен: у першому зразку жовчі частка вільних жирних кислот серед ліпідів досягає $18 \%$, а фосфоліпідів дещо зменшується (58\%). При цьому холестеролу, як і у групі I,

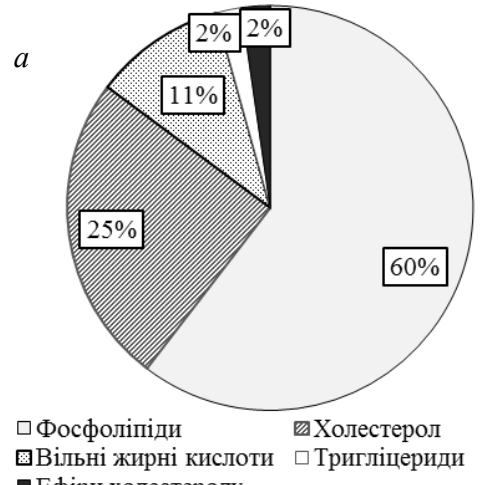

—Ефіри холестеролу

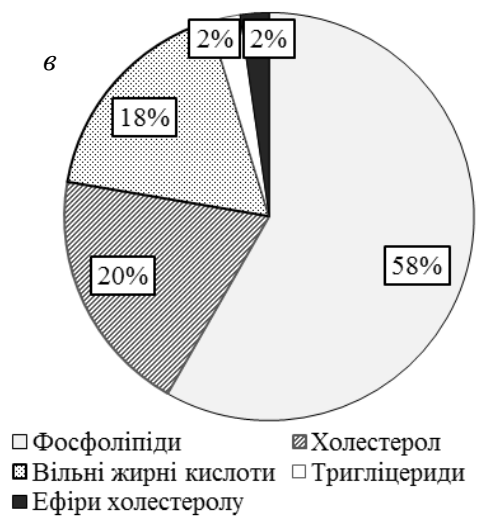

лишається 20\% (рис. 1). Склад першої проби жовчі, отриманої у групі III, показує, що уведення корвітину під час моделювання соціальної поразки у самців-інтрудерів викликало збільшення частки вільних жирних кислот до $17 \%$ і етерів холестеролу до $3 \%$ з одночасним зменшенням частки вільного холестролу до $18 \%$ та підтриманням вмісту фосфоліпідів на тому ж рівні, що й у контролі (рис. 1).

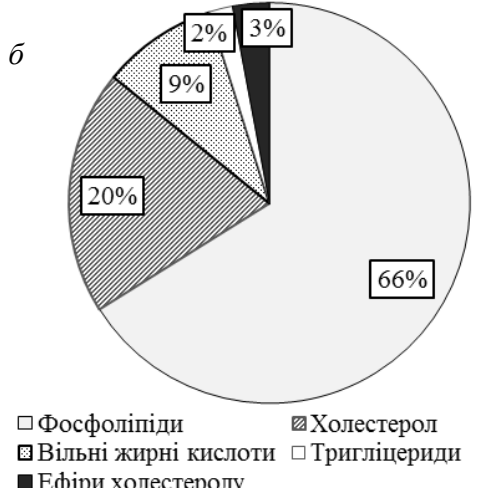

—Ефіри холестеролу

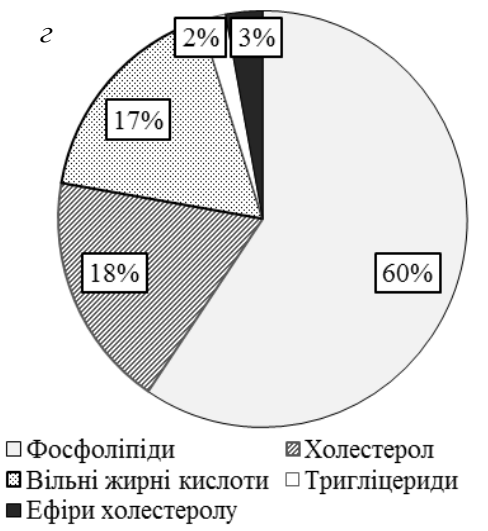

Рис. 1. Співвідношення ліпідів у першій пробі жовчі самців щурів під час хронічного соціального стресу та застосування корвітину: вказано відсоткову частку кожної ліпідної фракції в контролі (a), групах I (б), II (в) та III (2); n = 21

Значною мірою вплив соціального стресу на ліпідний склад жовчі виявляється у різній динаміці підтримання співвідношення різних ліпідів у печінковому секреті впродовж гострого досліду. Хоча концентрація фосфоліпідів у шостій пробі жовчі групи I була меншою за контроль (табл. 1), частка цього ліпідного компонента склала $65 \%$ загального вмісту ліпідів у печінковому секреті, а частка вільних жирних кислот лишилася низькою (10\%). Як у контролі, так і у групі I у шостій пробі частка холестеролу серед усіх інших ліпідних фракцій ставала меншою порівняно з першою півгодинною пробою жовчі. Відсоток тригліцеридів серед усіх ліпідів жовчі лишався незмінним упродовж усього гострого досліду як у контролі, так і у групі I - 2\% і 3\% відповідно (рис. 2).

У групі II частки фосфоліпідів, холестеролу та тригліцеридів серед усіх визначених фракцій ліпідів у шостому зразку жовчі лишилися тикими, як і у першій пробі, частка вільних жирних кислот дещо зменшилася (17\%), а частка етерів холестеролу збільшилася до 3\% (рис. 2). У щурів-інтрудерів, які отримували корвітин, у шостій пробі жовчі зменшилася лише частка фосфоліпідів: $57 \%$, порівняно $360 \%$ у першій пробі. При цьому у шостій пробі жовчі групи III збільшилися до 19\% і 3\% частки вільних жирних кислот і тригліцеридів, відповідно. Відсоток холестеролу та його етерів серед усіх визначених ліпідів жовчі у шостій пробі групи III лишався таким самим, як і у першій пробі (рис. 2).

Фізико-хімічні властивості жовчі, зокрема, ії колоїдна стабільність та літогенність можуть бути успішно оцінені за відповідними співвідношеннями різних ліпідних компонентів. У самців щурів групи I холато-холестероловий коефіцієнт жовчі першої та другої проб вищий від контролю на $27 \%$ та $25 \%(\mathrm{P}<0,05)$ відповідно. Також холато-холестероловий коефіцієнт жовчі у першій та другій пробах збільшувався порівняно з контролем на $33 \%$ (P < $0,05)$ та $32 \%(\mathrm{P}<0,05)$ у шурів самців за хронічного соціального стресу та застосування корвітину (група III). Натомість у групі II в четвертому, п'ятому та шостому зразках жовчі холато-холестероловий коефіцієнт був меншим від контролю на 21\%, 20\% (P < $0,05)$ та $28 \%(\mathrm{P}<0,05$; табл. 3$)$. Отже, за розрахунками холатохолестеролового співвідношення бачимо, що літогенні властивості жовчі (зростання ймовірності утворення холестеролових жовчних каменів) виявляються через місяць по тому як тварини зазнали соціального стресу.

Коефіцієнт етерифікації жовчі щурів у групі I менший за контроль у всіх шести пробах, відповідно на 40\% (P < 0,01), 38\% ( $<<0,05), 36 \%(\mathrm{P}<0,01), 44 \%(\mathrm{P}<0,001), 44 \%(\mathrm{P}<0,01)$ та $31 \%$. У групі II коефіцієнт етерифікації жовчі самців щурів за хронічного соціального стресу також менший за контроль протягом усього гострого досліду (шість проб) на 26\%, 31\% ( $\mathrm{P}<0,05), 34 \%(\mathrm{P}<0,01), 32 \%(\mathrm{P}<0,05), 31 \%(\mathrm{P}<0,05), 20 \%$. У тварин, які інтрагастрально отримували впродовж другого тижня стресування корвітин (група III), коефіціснт етерифікації був меншим від контролю у шести зразках жовчі на $42 \%$ (P < 0,05), 47\% ( $\mathrm{P}<0,01), 52 \%(\mathrm{P}<0,01), 42 \%(\mathrm{P}<0,01), 46 \%(\mathrm{P}<$ $0,01)$ та $45 \%$ ( $>0,01$; табл. 3). Оскільки коефіцієнт етерифікації розраховується як співідношення вільного холестеролу до етерифікованого, зменшення його значення вказує на посилення процесів етерифікації холестеролу у клітинах печінки як в 
умовах стресу, так і за застосування корвітину. Співвідношення фосфоліпідів і холестеролу жовчі шурів самців у групі I у всіх шести пробах було більше контролю на $33 \%$ (P < 0,01), 36\% (P < 0,01), 29\% ( $\mathrm{P}<0,05), 36 \%$ ( $<<0,01), 37 \%(\mathrm{P}<0,05), 30 \%(\mathrm{P}<$ $0,05)$. У самців щурів групи II співвідношення фосфоліпідів і холестеролу було у першій i другій пробах жовчі статистично значимо більше контролю на $21 \%(\mathrm{P}<0,05)$ і $19 \%(\mathrm{P}<0,05)$ відповідно (табл. 3). У групі ІІІ співвідношення фосфоліпідів і холестеролу жовчі щурів у першому зразку більше контролю на $26 \%$ (P $<0,01)$, у другому - на $25 \%$ ( $\mathrm{P}<0,01)$, третьому - на $20 \%$ (P $<0,05$; табл. 3). Виявлене збільшення описаного співвідношення пов'язане не 3 посиленим надходженням фосфоліпідів до жовчних канальців, а зі зменшенням вмісту холестеролу в жовчі стресованих самців щурів.

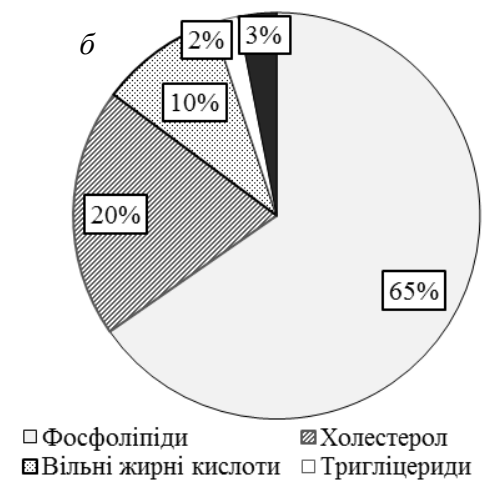

-Ефіри холестеролу

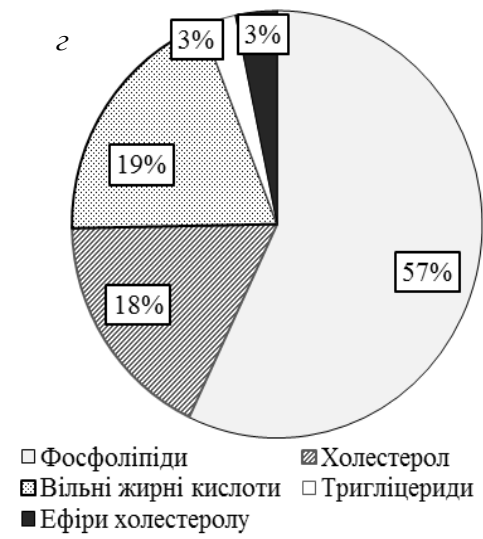

Рис. 2. Співвідношення ліпідів у шостій пробі жовчі щурів самців під час хронічного соціального стресу та застосування корвітину: вказано відсоткову частку кожної ліпідної фракції в контролі (a), групах I (б), II (в) та III (2); n = 21

\section{Обговорення}

У тварин, які тільки-но зазнали процедури стресування, печінка не здатна забезпечувати вміст фосфоліпідів у жовчі на достатньому рівні впродовж усього експерименту та наприкінці гострого досліду концентрація цих складових печінкового секрету знижується. 3 огляду на значення фосфоліпідів жовчі як їі ліпідних компонентів, що захищають клітини стінок первинних жовчних протоків та всього біліарного дерева від детергентних впливів холатів (Nicolaou et al., 2015) та стабілізують колоїдну систему жовчі, утримуючи (разом із жовчними кислотами) холестерол у складі міцел і таким чином запобігаючи його випаданню в осад (Wang et al., 2009, Boyer, 2013; Linton, 2015), зменшення концентрації фосфоліпідів у печінковому секреті можна вважати ще одним патологічним наслідком соціального стресу. Але слід зауважити, що фосфоліпіди потрапляють до жовчі внаслідок детергентного впливу холатів на каналікулярні ділянки плазматичних мембран гепатоцитів (Воyer, 2013). Надмірне зростання їх концентрації можливе лише за збільшення вмісту в жовчних канальцях аномальних жовчних кислот. У такому випадку виникатимуть розлади функціонування та структури мембран клітин печінки через порушення їх нормального складу. Оскільки співвідношення фосфоліпідів до холестеролу та холато-холестероловий коефіцієнт жовчі стресованих тварин збільшувалися, в умовах створеної нами моделі хронічного соціального стресу не зростав ризик холелітіазу. Однак через місяць після процедури стресування співвідношення фосфоліпідів до холестеролу залишається вищим контролю, але холато-холестероловий коефіцієнт жовчі знижується, а отже, погіршуються солюбілізаційні властивості печінкового секрету.

Синтез і етерифікація холестеролу пригнічується за різних уражень печінки, зокрема, холестазу. Найбільше зростання холато-холестеролового коефіціснта саме у групі III підтверджує припущення про можливі антихолелітичні властивості корвітину. Посилення етерифікації холестеролу, яке спостерігається в цих умовах, сприяє його утриманню у жовчних міцелах. Разом із тим, слід зазначити, що зміни коефіцієнта етерифікації у групах I і II вказують на посилене утворення етерів холестеролу в умовах соціального стресу та через місяць після стресування. Збільшення в крові рівня етерів холестеролу 3 насиченими та мононенасиченими жирними кислотами спричинює погіршення його трансмембранного транспорту до клітин і посиленої кристалізації, а відтак, його накопичення у судинному руслі з наступним відкладенням на стінках судин (Dlyaboha, 2012). Для з'ясування патогенетичної ролі виявленого нами посилення етерифікації холестеролу в умовах хронічного соціального стресу потрібні подальші дослідження, зокрема, жирнокислотного складу етерів холестеролу.

Зменшення концентрації вільних жирних кислот у жовчі стресованих щурів, яке спостерігалося одразу після завершення процедури стресування, може вказувати на інтенсифікацію використання цих речовин у реакціях енергетичного обміну в організмі тварин. Ймовірно, що істотне збільшення вмісту 
вільних жирних кислот у щурів групи II може бути пов'язане 3 посиленням їх виходу з відповідних депо, що не супроводжувалося належною утилізацією в тканинах організму. Такі розлади можуть бути наслідком хронічного психосоціального стресу, оскільки його характерна риса - ліпідна дисрегуляція (Gautam et al., 2015). Виявлені особливості ліпідного обміну та жовчоутворення за соціального стресу, як і викликане корвітином збільшення концентрації вільних жирних кислот і тригліцеридів у жовчі щурів групи III, потребують ретельного подальшого вивчення. Дослідження жовчі тварин в умовах екс- периментального соціального стресу дозволить не тільки розширити існуючі уявлення про порушення ліпідного обміну в стресових ситуаціях, а й відкрити нові аспекти участі гепатобіліарної системи у патогенезі стрес-індукованих захворювань. Хронічний соціальний стрес викликає певні зміни співвідношення ліпідів у жовчі, що слід враховувати для корекції стресіндукованих патологій. Зважаючи на отримані нами результати, необхідно проводити подалыші дослідження для пошуку ефективних гепатотропних препаратів для надання комплексної допомоги в умовах хронічного соціального стресу.

\section{Таблиця 3}

Холато-холестероловий коефіцієнт, коефіцієнт етерифікації та співвідношення фосфоліпідів і холестеролу жовчі щурів самців за хронічного соціального стресу та застосування корвітину $\left(1 \mathrm{мг} / \kappa г, \mathrm{Me}\left[\mathrm{Q}_{25} ; \mathrm{Q}_{75}\right]\right.$, мг\%, $\left.\mathrm{n}=21\right)$

\begin{tabular}{|c|c|c|c|c|}
\hline Проби жовчі & Серія & Холато-холестероловий коефіцієнт & Коефіцієнт етерифікації & $\begin{array}{c}\text { Співвідношення фосфоліпідів } \\
\text { до холестеролу }\end{array}$ \\
\hline \multirow{4}{*}{1} & контроль & $15,06[14,36 ; 15,78]$ & $11,03[9,10 ; 13,13]$ & $2,16[2,02 ; 2,56]$ \\
\hline & група I & $19,05[16,75 ; 19,47]$ & $6,58[6,35 ; 7,01]^{* *}$ & $2,87[2,76 ; 3,05]^{* *}$ \\
\hline & група II & $17,57[15,38 ; 18,54]$ & $8,21[7,64 ; 9,95]$ & $2,62[2,55 ; 2,87]^{*}$ \\
\hline & група III & $19,98[18,51 ; 20,35]^{*}$ & $6,45[5,69 ; 7,07]^{*}$ & $2,73[2,71 ; 2,78]^{* *}$ \\
\hline \multirow{4}{*}{2} & контроль & $14,49[14,18 ; 15,62]$ & $11,60[9,96 ; 14,05]$ & $2,18[2,04 ; 2,50]$ \\
\hline & група I & $18,12[17,13 ; 19,05]^{*}$ & $7,24[6,58 ; 7,90]^{*}$ & $2,97[2,83 ; 3,23]^{* *}$ \\
\hline & група II & $14,90[13,78 ; 16,79]$ & $7,98[7,39 ; 9,91]^{*}$ & $2,59[2,53 ; 2,70]^{*}$ \\
\hline & група III & $19,16[18,03 ; 19,73]^{*}$ & $6,19[5,62 ; 6,75]^{* *}$ & $2,72[2,69 ; 2,77]^{* *}$ \\
\hline \multirow{4}{*}{3} & контроль & $14,96[14,00 ; 16,94]$ & $11,34[9,69 ; 12,89]$ & $2,24[2,06 ; 2,57]$ \\
\hline & група I & $15,78[14,73 ; 18,52]$ & $7,24[7,06 ; 7,62]^{* *}$ & $2,88[2,66 ; 3,08]^{*}$ \\
\hline & група II & $13,34[13,01 ; 13,49]^{*}$ & $7,51[7,21 ; 8,72]^{* *}$ & $2,61[2,45 ; 2,67]$ \\
\hline & група III & $18,98[18,49 ; 19,22]^{*}$ & $5,49[5,24 ; 6,88]^{* *}$ & $2,68[2,67 ; 2,79]^{*}$ \\
\hline \multirow{4}{*}{4} & контроль & $15,21[13,82 ; 17,55]$ & $11,24[9,64 ; 13,65]$ & $2,21[2,14 ; 2,79]$ \\
\hline & група I & $15,05[11,82 ; 13,01]^{*}$ & $6,35[6,15 ; 6,61]^{* * *}$ & $3,01[2,86 ; 3,13]^{* *}$ \\
\hline & група II & $12,05[13,50 ; 16,60]$ & $7,61[7,09 ; 8,71]^{*}$ & $2,61[2,58 ; 2,72]$ \\
\hline & група III & $17,65[15,62 ; 18,56]$ & $6,58[4,94 ; 6,60]^{* *}$ & $2,77[2,68 ; 2,77]$ \\
\hline \multirow{4}{*}{5} & контроль & $14,97[13,74 ; 18,27]$ & $10,70[7,94 ; 12,22]$ & $2,25[2,17 ; 2,79]$ \\
\hline & група I & $15,61[13,79 ; 17,46]$ & $5,97[5,73 ; 6,70]^{* *}$ & $3,09[3,05 ; 3,05]^{*}$ \\
\hline & група II & $11,91[11,18 ; 12,66]^{*}$ & $7,42[7,00 ; 9,32]^{*}$ & $2,72[2,59 ; 2,87]$ \\
\hline & група III & $16,81[15,80 ; 17,20]$ & $5,82[5,24 ; 6,88]^{* *}$ & $2,72[2,16 ; 2,64]$ \\
\hline \multirow{4}{*}{6} & контроль & $14,53[13,24 ; 17,02]$ & $9,41[8,24 ; 12,96]$ & $2,24[2,15 ; 2,64]$ \\
\hline & група I & $15,25[14,26 ; 16,40]$ & $6,52[5,54 ; 7,09]^{* *}$ & $2,90[2,64 ; 3,07]^{*}$ \\
\hline & група II & $10,44[9,67 ; 10,90]^{*}$ & $7,55[6,81 ; 9,09]$ & $2,58[2,56 ; 2,69]$ \\
\hline & група III & $14,98[14,84 ; 15,35]$ & $5,19[4,82 ; 6,22]^{* *}$ & $2,76[2,69 ; 2,77]$ \\
\hline
\end{tabular}

Примітки: див. табл. 1

\section{Висновок}

У самців щурів, які зазнали експериментального хронічного соціального стресу, порушувалися процеси обміну холестеролу в печінці, що викликало зниження концентрації вільного холестеролу в жовчі та посилення його етерифікації в клітинах печінки, як одразу після завершення стресування, так і через місяць після нього. Крім того, одразу після стресування самців щурів у їх жовчі зменшувався вміст фосфоліпідів. Застосування корвітину одночасно $з$ моделюванням соціального стресу викликало зменшення вмісту вільного холестеролу та збільшення кількості його етерів у жовчі самців щурів із підтриманням концентрації фосфоліпідів на контрольному рівні. Посилене використання жирних кислот у метаболічних реакціях в організмі стресованих тварин викликало зниження їх концентрації у жовчі одразу після моделювання хронічного соціального стресу. Але через місяць по тому як тварини зазнали експериментального хронічного стресу концентрація вільних жирних кислот у печінковому секреті зростала. У жовчі щурів, які зазнавали соціальної поразки та отримували корвітин, концентрація вільних жирних кислот і тригліцеридів збілышувалася. Виявлені зміни концентрації ліпідів у жовчі вказують на суттєві зміни їх розподілу в організмі самців щурів за умов експериментального хронічного соціального стресу та застосування у процесі стресування корвітину. Значна тривалість і специфічна динаміка в часі змін ліпідного складу жовчі за хронічного соціального стресу потребують подальшого вивчення для з'ясування їх патогенетичної ролі та пошуку ефективних засобів корекції.

\section{References}

Boyer, J. L. (2013). Bile formation and secretion. Comprehensive Physiology, 3(3), 1035-1078.

Chuang, J. C., Cui, H., Mason, B. L., Mahgoub, M. L., Bookout, A. L., Yu, H. G. Perello, M., Elmquist, J. K., Repa, J. J., Zigman, J. M., \& Lutter, M. (2010). Chronic social defeat stress disrupts regulation of lipid synthesis. Journal of Lipid Research, 51(6), 1344-1353.

Dlyaboha, Y. Z. (2012). Korektsiya zhymokyslotnoho skladu eteryfikovanoho kholesterolu v orhanizmi ta rist shchuriv za eksperymental'noyi hiperkholesterynemiyi [Correction of fatty acid composition of esterified cholesterol in the body and growth of rats in experimental hypercholesterolemia]. Visnyk of Dnipropetrovsk University. Biology, Medicine, 3(1), 29-37 (in Ukranian).

Eckstein, J., Berndt, N., \& Holzhütter, H.-G. (2015). Computer simulations suggest a key role of membranous nanodomains in biliary lipid secretion. PLOS Computational Biology, 11(2), e1004033.

Faylon, M. P., Baumgard, L. H., Rhoads, R. P., \& Spurlock, D. M. (2015). Effects of acute heat stress on lipid metabolism of bovine primary adipocytes. Journal of Dairy Science, 98(12), 8732-8740.

Filimonova, N. B., \& Fil', I. O. (2005). Statystychnyy analiz danykh vidpovidno do zasad naukovo obgnuntovanoyi medytsyny. Porivnyannya hrup za kil'kisnymy pokaznykamy [Statistical analysis of data according to the principles of science-based medicine. Comparison of groups in quantitative terms]. Medytsyna Zaliznychnoho Transportu Ukrayiny, 4, 86-93 (in Ukranian).

Filimonova, N. B., Fil', I. O., \& Mykhaylova, T. S. (2004). Statystychnyy analiz danykh vidpovidno do zasad naukovo obgruntovanoyi medytsyny. Pervynnyy analiz kil'kisnykh danykh, podannya rezul'tativ eksperymentu [Statistical analysis of data according to the principles of science-based medicine Initial analysis of quantitative data, presentation of experimental results]. Medytsyna Zaliznychnoho Transportu Ukrayiny, 4, 30-38 (in Ukranian).

Ganitkevich, J. V., \& Karbach, J. I. (1985). Issledovanie zhelchi. Biohimicheskie i biofizicheskie metody [Investigation of bile. Biochemical and biophysical methods]. Higher School, Kyiv (in Russian). 
Gautam, A., D’Arpa, P., Donohue, D. E., Muhie, S., Chakraborty, N., Luke, B. T. Grapov, D., Carroll, E. E., Meyerhoff, J. L., Hammamieh, R., \& Jett, M. (2015). Acute and chronic plasma metabolomic and liver transcriptomic stress effects in a mouse model with features of post-traumatic stress disorder. Public Library of Science, 10(1), e0117092.

Han, J., \& Kaufman, R. J. (2016). The role of ER stress in lipid metabolism and lipotoxicity. Journal of Lipid Research, 57(8), 1329-1338.

Horid'ko, T. M., Kosiakova, H. V., Berdyshev, A. G., Meged, O. F., Gudz, E. A., Onopchenko, O. V., Asmolkova, V. S., Lozova, V. M., Tukalenko, E. V., Bondarenko, O. V., Tubalzeva, I. I., Kovalenko, O. A., Makarchuk, M. Y., \& Hula, N. M. (2017). Antistress effects of N-stearoylethanolamine in rats with chronic social stress. Ukrainian Biochemical Journal, 89(4), 68-76.

Hşmioğullari, A. A., Bozdayi, A. M., \& Rahman, K. (2007). Biliary lipid secretion. Turkish Journal of Gastroenterology, 18(2), 65-70.

Kudryavtseva, N. N. (1991). A sensory contact model for the study of aggressive and submissive behavior in male mice. Aggressive Behavior, 17(5), 285-291.

Liashevych, A. M., Reshetnik, Y. M., Syechyna, I. M., Vesel's'kyy, S. P., \& Hamyk, K. V. (2016). Vplyv korvitynu na biotransformatsiyu zhovchnykh kyslot u pechintsi shchuriv z eksperymental'noyu hiperkholesterynemiyeyu [Effect of corvitin on biotransformation of bile acids in the liver of rats with experimental hypercholesterolemia]. Phytotherapy, 4, 12-16 (in Ukranian).

Linton, K. J. (2015). Lipid flopping in the liver. Biochemical Society Transactions, 43(5), 1003-1010.

Liu, Y. Z., Chen, J.-K., Zhang, Y., Wang, X., Qu, S., \& Jiang, C.-L. (2014). Chronic stress induces steatohepatitis while decreases visceral fat mass in mice. BioMed Central Gastroenterology, 14, 106.

Nicolaou, M., Andress, E. J., Zolnerciks, J. K., Dixon, P. H., Williamson, C., \& Linton, K. J. (2012). Canalicular ABC transporters and liver disease. Journal of Pathology, 226(2), 300-315.
Scott, K. A., Melhorn, S. J., \& Sakai, R. R. (2012). Effects of chronic social stress on obesity. Current Obesity Reports, 1(1), 16-25.

Tyazhka, O. V., Smishchuk, V. V., \& Bryuzhina, T. S. (2015). Znachennya biokhimichnoho doslidzhennya zhovchi yak indykatora porushen' metabolizmu zhyrnykh kyslot, fosfolipidiv ta kholesterynu v ditey z kholelitiazom [The value of biochemical research bile as an indicator of metabolic disorders of fatty acids, phospholipids and cholesterol in children with cholelithiasis]. Perynatolohiya i Pediatriya, 61, 63-67 (in Ukranian).

Vesel's'kyy, S. P., Lyashchenko, P. S., Kostenko, S. I., Horenko, Z. A., \& Kurovs'ka, L. F. (2001). Sposib pidhotovky prob bioridyn dlya vyznachennya vmistu rechovyn lipidnoyi pryrody [Method of preparation of samples of bioridines to determine the content of substances of lipid nature]. Pat. 99031324 (in Ukranian).

Vovkun, T. V., Yanchuk, P. I., Shtanova, L. Y., Vesel's'kyy, S. P., \& Shalamay, A. S. (2016). Zovnishn'osekretorna funktsiya pechinky shchuriv pry diyi korvitynu [Exocrine function of the liver in rats with exposure to corvitin]. Fiziologichnyi Zhurnal, 62(3), 30-38 (in Ukranian).

Wang, D. Q., Cohen, D. E., \& Carey, M. C. (2009). Biliary lipids and cholesterol gallstone disease. Journal of Lipid Research, 50, S406-411.

Wirtz, P. H., Ehlert, U., Bärtschi, C., Redwine, L. S., \& Känel, R. (2009). Changes in plasma lipids with psychosocial stress are related to hypertension status and the norepinephrine stress response. Metabolism: Clinical and Experimental, 58(1), 30-37.

Zahayko, A. L., Voronina, L. M., Kaliman, P. A., \& Strel'chenko, K. V. (2008). Vplyv khronichnoho sotsial'noho stresu na metabolizm lipidiv u zolotystykh syriys'kykh khom'yachkiv [Influence of chronic social stress on lipid metabolism in golden hamsters Syria]. Ukrainian Biochemical Journal, 80(4), 120-128 (in Ukranian). 